\title{
Brain Iron Homeostasis: A Focus on Microglial Iron
}

\author{
Israel C. Nnah and Marianne Wessling-Resnick * \\ Department of Genetics and Complex Diseases, Harvard TH Chan School of Public Health, Boston, MA 02115, \\ USA; innah@hsph.harvard.edu \\ * Correspondence: wessling@hsph.harvard.edu
}

Received: 17 October 2018; Accepted: 19 November 2018; Published: 23 November 2018

\begin{abstract}
Iron is an essential trace element required for important brain functions including oxidative metabolism, synaptic plasticity, myelination, and the synthesis of neurotransmitters. Disruptions in brain iron homeostasis underlie many neurodegenerative diseases. Increasing evidence suggests that accumulation of brain iron and chronic neuroinflammation, characterized by microglia activation and secretion of proinflammatory cytokines, are hallmarks of neurodegenerative disorders including Alzheimer' s disease. While substantial efforts have led to an increased understanding of iron metabolism and the role of microglial cells in neuroinflammation, important questions still remain unanswered. Whether or not increased brain iron augments the inflammatory responses of microglial cells, including the molecular cues that guide such responses, is still unclear. How these brain macrophages accumulate, store, and utilize intracellular iron to carry out their various functions under normal and disease conditions is incompletely understood. Here, we describe the known and emerging mechanisms involved in microglial cell iron transport and metabolism as well as inflammatory responses in the brain, with a focus on AD.
\end{abstract}

Keywords: Alzheimer's disease; neuroinflammation; neurodegeneration; cytokines; neuroimmune responses

\section{Introduction}

The brain is among the most metabolically active organs in the body and accounts for at least $20 \%$ of the body's energy consumption. Accordingly, an adequate supply of iron is necessary to sustain its high-energy needs [1-4]. Our understanding of the role of iron in normal brain function has improved tremendously over the last decade, with much attention directed towards deciphering the cellular and molecular cues that guide brain iron transport and metabolism. These efforts have described the essential roles of iron as a co-factor for several physiological processes including oxidative metabolism, myelination, and the biosynthesis of neurotransmitters [5-7]. However, excess iron is known to contribute to homeostatic dysregulation due to oxidative stress and has been linked to a number of neurological disorders. Being redox active, iron exists in both ferrous $\left(\mathrm{Fe}^{2+}\right)$ and ferric $\left(\mathrm{Fe}^{3+}\right)$ forms and constantly cycles between the two states. Under aerobic conditions, this redox cycling has the potential to generate highly reactive free radicals through Fenton chemistry, resulting in oxidative stress and damage to macromolecules. Thus, the metal is directly implicated in the disease known as neurodegeneration with brain iron accumulation (NBIA), and, in addition to other trace elements implicated in neurodegeneration, including copper [8], manganese [9], and zinc [10], increasing evidence support iron's role in several other sporadic or genetic neurodegenerative disorders such as Alzheimer's disease (AD), Parkinson's disease (PD), Huntington's disease (HD), amyotrophic lateral sclerosis (ALS), and multiple sclerosis (MS) [11-14].

Microglia make up 5 to $12 \%$ of the population of cells found in mouse brain and about 0.5 to $16 \%$ of those in the human brain $[15,16]$. These resident macrophages are largely involved in immune 
responses and, depending on the stimuli, they can adopt a range of pro- or anti-inflammatory states to help maintain the integrity of the neural environment [17-19]. In addition to their roles in the neuroinflammatory response, microglia participate in neurogenesis $[19,20]$, shaping and maintaining synaptic density and connectivity in the adult and developing central nervous system (CNS) [16,21-24], oligodendrocyte differentiation [25], synaptic pruning [26], and myelin repair [16]. Microglia require iron as a co-factor to carry out all of these varied functions [27]. Over the years, multiple studies have reported the roles these immune cells play in brain iron homeostasis $[1,27,28]$. This review will examine the influence of brain iron on microglial metabolism and corresponding inflammatory responses under normal and neurodegenerative conditions, with a particular focus on AD.

\section{Brain Iron}

Brain iron levels are tightly regulated to ensure the normal function of the CNS [29,30]. The major route of iron acquisition begins with intestinal absorption, as dietary $\mathrm{Fe}^{3+}$ is reduced to $\mathrm{Fe}^{2+}$ by duodenal cytochrome B (DcytB) at the apical surface of enterocytes [31]. Divalent metal transporter-1 (DMT1) imports $\mathrm{Fe}^{2+}$ into the intestinal cells, while the iron exporter ferroportin (Fpn) mediates its exit across this epithelial barrier. On the serosal side, the multicopper ferroxidases ceruloplasmin and/or hephaestin oxidize $\mathrm{Fe}^{2+}$ to $\mathrm{Fe}^{3+}$, thereby promoting its binding to the iron carrier protein transferrin (Tf) [32]. Dietary absorption of iron is tightly regulated to respond to the body's iron needs, such that uptake is enhanced by iron deficiency but reduced under iron-loading conditions [29]. Thus, iron supplied to the brain from the diet reflects nutrient demands, while limiting the potential for excessive accumulation.

Once in the circulation, the entry of iron into the brain from the blood is controlled by the blood-brain barrier (BBB) [33]. The BBB is formed by brain microvascular endothelial cells (BMVECs), pericytes, and astrocytes [33-35]. Tf-bound iron circulating in the blood outside the CNS cannot cross the BBB directly, and, therefore, iron must enter the brain through BMVECs in a multi-step transcellular pathway. Binding of $\mathrm{Tf}$ to $\mathrm{Tf}$ receptors (TfR) at the lumen of the brain microvasculature facilitates iron uptake via receptor-mediated endocytosis $[30,34,36]$. The subsequent fate of the Tf-TfR complex within brain endothelial cells is not entirely clear, and exactly how iron is released to the brain remains controversial. The transcytosis model suggests that the ligand-receptor complex traverses the cell, such that $\mathrm{Tf}$ is released to the interstitium. However, how $\mathrm{Tf}$ might dissociate from its receptor at the abluminal membrane remains unexplained. An alternative model is that iron is released to the cytoplasm of BMVECs after receptor-mediated endocytosis of Tf. The endocytic uptake pathway for iron is much better understood and involves the release of $\mathrm{Fe}^{3+}$ from $\mathrm{Tf}$ in the acidic endosomal environment, its reduction to $\mathrm{Fe}^{2+}$, and DMT1-mediated export from the endosome [29]. However, whether BMVECs express DMT1 or if its function is required for entry of iron into the brain is unclear, since different groups have reported conflicting data [37-42]. An alternative membrane transport mechanism could involve transient receptor potential mucolipin-1 (TRPML1) channels which function in the release of iron from endolysosomal compartments [43]. A recent study has shown that loss of TRPML1 in mice promotes dysregulation of brain homeostasis and decreased myelination, suggesting a potential role in brain iron uptake [44]. Regardless of which transporter is responsible for iron's exit from endocytic compartments, the metal would then be utilized for metabolic purposes by the endothelial cells, stored in endothelial cell ferritin (Ftn), or released to the brain via Fpn [45]. Re-oxidation of $\mathrm{Fe}^{2+}$ to $\mathrm{Fe}^{3+}$ and subsequent incorporation into apo-Tf would provide for its circulation in the brain [46-48]. It is possible that hepcidin, which is produced by the brain endothelium, plays a role in regulating this process. An in-depth review of iron uptake into BMVECs and its release has been published elsewhere [33].

It is important to note that the amount of $\mathrm{Tf}$ in the brain interstitial fluid is thought to be much lower than the levels in the systemic circulation, while non-Tf-bound iron (NTBI) levels may be quite high [49]. Thus, although Tf is apparently involved in moving iron across the BBB, there is some evidence to suggest that Tf-iron-binding sites may become saturated in the brain, such that 
NTBI is a major source of iron delivery to neurons and other cells in the brain. Another alternative source of iron is ferritin which plays an important role in brain iron homeostasis. In fact, genetic loss of ferritin function leads to brain iron dyshomeostasis [11,50-52]. The brain may acquire ferritin exogenously by transcellular transport across the BBB, or it may be produced by endothelial cells and released upon demand [53]. Other endogenous sources of brain ferritin are possible, including its synthesis by microglia [28]. The ferritin pathway of iron delivery is particularly important for mouse oligodendrocytes and their function in myelination and neuronal repair. These express the ferritin receptor Tim-2, a member of the $\mathrm{T}$ cell immunoglobulin and mucin domain family, and specifically take up ferritin $[6,54]$. In humans, the transferrin receptor may bind to and mediate the internalization of ferritin $[55,56]$.

\section{Functions of Iron in the Brain}

Iron plays an indispensable role during ATP production by serving as a cofactor for cytochromes and iron-sulfur complexes of the oxidative chain [57]. The major substrate for brain energy production is glucose which becomes fully oxidized; ketone bodies can fulfill energy needs under some conditions. The brain consumes nearly $20 \%$ of the body's energy, although representing only about $2 \%$ of its weight. About $75-80 \%$ of the energy supports neuronal activity, with the remainder utilized to maintain the "housekeeping" functions of astrocytes, oligodendrocytes, and microglia [4]. Neuronal energy needs represent both axonal and synaptic signaling, but the majority is utilized post-synaptically [58]. The mitochondrial function must provide this supply of ATP with the iron requirements to support oxidative phosphorylation, as shown in Figure 1.

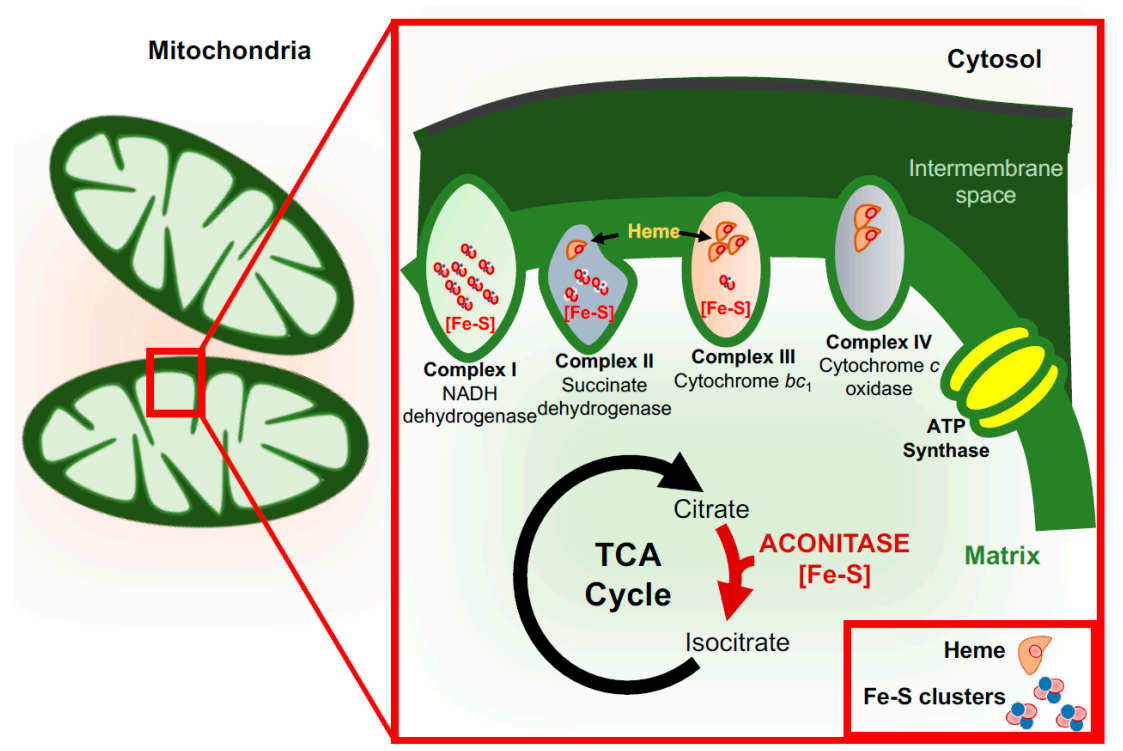

Figure 1. Iron and mitochondrial function. The mitochondrial electron transport chain contains multiple iron-sulfur clusters and heme-containing proteins necessary for ATP synthesis. NADH dehydrogenase (complex I) contains eight Fe-S clusters, succinate dehydrogenase (complex II) contains three Fe-S clusters and one heme moiety, while complex III (cytochrome bc1) contains one Fe-S cluster and several heme groups vital for its functions. Complex IV (cytochrome c oxidase) also contains two heme moieties. Aconitase, a key enzyme that catalyzes the stereo-specific isomerization of citrate to isocitrate through cis-aconitate in the tricarboxylic acid (TCA) cycle contain Fe-S clusters.

Oligodendrocytes, which are responsible for producing myelin, also require high amounts of ATP [59]. Not only do many of the enzymes involved in ATP production require a supply of iron, but also pathways for cholesterol and fatty acid synthesis necessary for myelination are iron-dependent. Some of the enzymes involved in this pathway include NADH dehydrogenase, HMG-CoA reductase, succinate dehydrogenase, dioxygenase, and glucose-6-phosphate dehydrogenase, all of which are 
abundant in oligodendrocytes compared to other cell types of the CNS [59]. The need for an adequate supply of iron during myelination is reflected in the results of animal studies demonstrating that dietary iron restriction reduces the amount and composition of myelin during gestation and early post-natal periods $[60,61]$.

Neurotransmitters serve as means of communication between neurons. The process of this communication includes biosynthesis and transport of neurotransmitters, packaging of neurotransmitters into vesicles for storage and controlled release, and binding of neurotransmitters to receptors on post-synaptic neurons with induction of cellular responses. The role of iron in each of these processes has been reviewed extensively, particularly in the case of monoamine neurotransmitters such as dopamine and serotonin that are involved in the regulation of cognitive processes including emotion and arousal behaviors [1,62-65]. For example, the synthesis of monoamine neurotransmitters depends on tyrosine hydroxylase which is an iron-requiring enzyme [66,67]. The activity of this enzyme is significantly reduced in patients suffering from PD with compromised brain iron homeostasis [67]. Iron deficiency further alters the functioning of the dopaminergic systems, with specific effects on dopamine $D_{1}$ and $D_{2}$ receptors $[1,68]$. Studies carried out by Youdim and colleagues demonstrated that the densities of dopamine $\mathrm{D}_{2}$ receptors are significantly lower in the striatum of rats deficient in iron [69-71]. Also, microdialysis studies demonstrated an elevation of extracellular dopamine in the striatum of iron-deficient rats and the return to basal levels when brain iron content and iron status returned to normal [72]. In the case of serotonin, tryptophan hydroxylase carries out the rate-determining step in the synthesis of this neurotransmitter and can be inhibited by iron chelators [66,73]. Another neurotransmitter whose biosynthesis is compromised under iron-deficient conditions is gamma-aminobutyric acid (GABA), the main inhibitory neurotransmitter in the CNS. Iron deficiency is associated with significant reduction in the activity of glutamate dehydrogenase and GABA transaminase, key enzymes responsible for the synthesis and degradation of GABA [74,75].

\section{Microglia and Iron}

Microglial activation in response to pro- and anti-inflammatory stimuli is often characterized either as classical M1 or as alternative M2, similar to the nomenclature used for systemic macrophages [76,77]. M1 activation is pro-inflammatory and neurotoxic and primarily induced through the activation of toll-like receptor (TLR) and interferon gamma (IFN- $\gamma$ ) signaling pathway [19]. M1 microglia synthesize and secrete pro-inflammatory cytokines and chemokines such as tumor necrosis factor-alpha (TNF- $\alpha$ ), some members of the interleukin family of cytokines interleukin-6 (IL-6), interleukin 1-beta (IL-1 $\beta$ ), interleukin-12 (IL-12), and C-C Motif Chemokine Ligand 2 (CCL2). In this reactive state, microglia also express inducible nitric oxide synthase (iNOS), which converts arginase into nitric oxide [19]. Accumulation of nitric oxide increases the toxic effects of glutamate and consequently potentiates $\mathrm{N}$-methyl-D-aspartate (NMDA) receptor-mediated neurotoxicity [19,78,79].

In the M2 state, microglia release anti-inflammatory cytokines such as interleukin-10 (IL-10) and transforming growth factor-beta (TGF- $\beta$ ). M2 microglia also induce arginase 1 to promote the conversion of arginine into polyamines [80]. These cells can secrete insulin-like growth factor I (IGF-I), fibroblast growth factor (FGF), and neurotrophic factors including nerve growth factor (NGF) and brain-derived neurotrophic factor (BDNF), in the effort to resolve inflammation and promote synaptic plasticity [19].

The use of the terms "M1 versus M2" oversimplifies a complex process for microglial activity, since transcriptome studies have revealed that activation is quite variable and context-dependent $[18,81]$. Indeed, microglia adopt a homeostatic (M0) state under normal conditions in the CNS, and their transcriptome profile reflects their immunosurveillance activities in this state [18,81-83]. Conversely, microglia can express both neurotoxic and neuroprotective factors under disease conditions $[19,81,84]$.

One prominent hallmark of neuroinflammation is the activation and increased acquisition of extracellular iron and subsequent downregulation of iron-interacting proteins, causing the intracellular sequestration of iron [13]. Systemically, such innate immune responses are orchestrated to deprive 
invading pathogens of iron, necessary for their survival [85]. This "iron withdrawal" phenomenon could play a similar role in the brain to reduce the metal's availability. However, accumulation of intracellular iron is associated with neuronal degeneration that underlies most neurological disorders [86], and microglial secretion of the inflammatory cytokines TNF- $\alpha$ and IL-1 $\beta$ enhances neuronal iron uptake [87]. In turn, these pro-inflammatory mediators have been shown to strongly influence microglia iron transport and metabolism [13,88-90].

Microglial cells interact with both Tf bound-iron (TBI) and NTBI [91], and pathways for each transport substrate have been characterized [28]. For NTBI uptake, an endogenous cell surface ferrireductase reduces $\mathrm{Fe}^{3+}$ to $\mathrm{Fe}^{2+}$ for uptake by DMT1 in a $\mathrm{pH}$-dependent manner at the cell surface. TBI is taken up by endocytosis of the Tf-TfR complex; after the release of iron in the acidic milieu of the endosome, it is translocated into the cytosol by DMT1 or other transporters, as described above [92].

Early studies of rat microglia raised the idea that microglial polarization and iron uptake are coordinated [89]. More recently, our group has shown that microglial iron transport pathways are differentially active in response to pro- and anti-inflammatory stimuli at both the transcript and the protein levels. Pro-inflammatory mediators increase the uptake of NTBI and expand the ferritin storage pool. These changes reflect the upregulation of both DMT1 and ferritin [28]. The uptake of NTBI by microglia would limit free extracellular iron and reduce potentially damaging reactive oxygen species (ROS) in the neural environment. In this M1 pro-inflammatory state, microglial cells also have increased glycolysis, with extracellular acidification supporting changes in the microenvironment favoring NTBI uptake by the pH-dependent transporter DMT1. Inflammatory mediators also reduce oxidative respiration, induce heme oxygenase-1, and diminish the levels of intracellular heme. These changes are associated with increased intracellular "labile iron", suggesting that microglia can sequester both intracellular iron released by heme catabolism and extracellular iron taken up by DMT1. In contrast, anti-inflammatory IL-4 increases the expression of TfR to promote the uptake of TBI [28]. It is possible that this shift in iron transport is associated with the release of ferritin stores by M2 microglia to support the regeneration of neurons and the activity of oligodendrocytes. On the basis of these data, we propose a model by which microglia actively modify transport pathways and metabolism in response to the iron status of their environment (Figure 2).
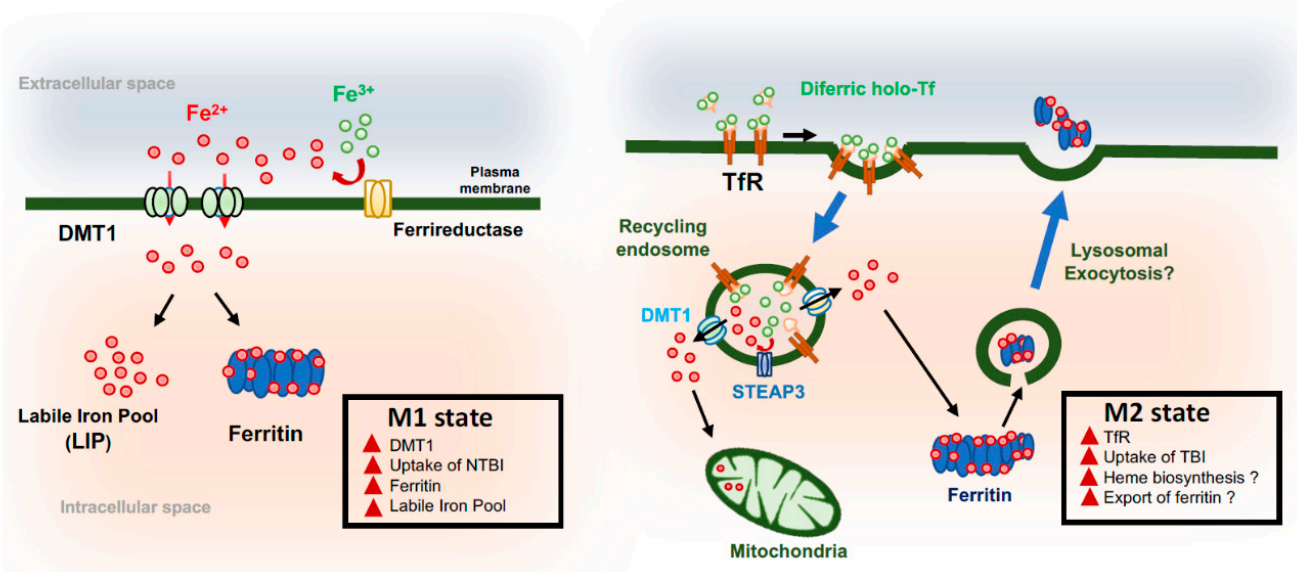

Figure 2. Iron trafficking and microglial cell polarization. (Left) Pro-inflammatory stimuli upregulate the expression of divalent metal transporter-1 (DMT-1) and the uptake of non-Tf-bound iron (NTBI). These effects are associated with increased labile iron and an expanded pool of ferritin. These changes reflect M1 polarization. (Right) Anti-inflammatory stimuli increase transferrin receptor (TfR) levels to upregulate Tf-bound iron (TBI) uptake by receptor-mediated endocytosis. In recycling endosomes, the low $\mathrm{pH}$ promotes the release of $\mathrm{Fe}^{3+}$ for ferrireduction, most likely by STEAP3. $\mathrm{Fe}^{2+}$ may be released into the cytosol through DMTI or another channel for use in mitochondria to promote heme production. We speculate that, under anti-inflammatory conditions, microglia may release ferritin (Ftn)-bound iron through lysosomal exocytosis to help oligodendrocyte function and neuronal repair. 


\section{Microglia Activation and Alzheimer's Disease}

Alzheimer's Disease (AD) is a neurodegenerative disorder and the most common form of dementia involving the progressive loss of substantive cortical and hippocampal neurons over time $[93,94]$. This disorder is characterized by extracellular deposition of amyloid beta $(A \beta)$ in senile plaques and intraneuronal accumulation of hyperphosphorylated tau proteins. These events lead to neuronal and synaptic loss, chronic inflammation, and oxidative stress $[19,89,95,96]$.

Genetic studies of familial Alzheimer's disease (FAD) have demonstrated that mutations in the amyloid precursor protein and in components of the gamma-secretase complex generate A $\beta 1-42$ which can misfold and aggregate $[19,93,97]$. The more common sporadic form (SAD) of the disease is largely associated with aging. Although the pathophysiological mechanisms that underlie the role of aging in the onset of AD is poorly understood, accumulating evidence indicates that the onset of SAD is closely associated with brain iron and oxidative stress, both of which increase with age [95,98-103]. In AD, the observation that iron is present in local areas of neuronal cell death further supports the metal theory of dementia which proposes that iron promotes neurodegeneration [104]. Furthermore, as brain microglia are implicated in iron handling, it has been shown that iron accumulates in microglial cells that cluster around amyloid plaques in AD mouse models and post-mortem brain tissues of AD patients [105].

Iron is a key player during the induction of oxidative stress because of its function as a redox-active transition metal $[13,96,106]$. Indeed, the levels of damaging ROS are significantly higher in the AD brain compared to healthy control brains [96,107]. Importantly, several studies have reported that, by promoting neurotoxic oligomerization of $\mathrm{A} \beta$ peptides and tau tangles [94,108], oxidative stress potentiates the activation of microglia $[96,109,110]$. Whether these events advance or hinder the disease is subject to active debate. For example, while anti-inflammatory activities of microglia would appear to be beneficial, some studies have reported that prolonged stimulation of microglia with $\mathrm{A} \beta$ peptides provokes chronic inflammation [111].

Microglial cells express multiple receptors including CD36, TLR2, TLR4, and TLR6 [111-113], all of which can bind $A \beta$ and induce pro-inflammatory effects. The sporadic form of AD is associated with genetic variants of triggering receptor expressed on myeloid cells 2 (TREM2) [114]. TREM2 is an immune transmembrane glycoprotein receptor expressed in microglia that interacts with phospholipids, apoptotic cells, and lipoproteins [115-118]. These variants, as well as the loss-of-function mouse models of $\mathrm{AD}$, appear to limit microglial proliferation around $\mathrm{A} \beta$ plaques, causing increased plaque buildup and disease progression [119-122]. Why defective TREM2 function or expression impacts microglia responses to AD lesion is still incompletely understood. The role of TREM2 and other immune receptors identified as risk factors, including CD33, have been reviewed elsewhere [19].

SAD is also associated with the polymorphism of apolipoprotein E (apoE), a lipid-binding protein involved in lipid metabolism [123-125]. The apoE4 allele is strongly associated with an increased risk of AD, while apoE2 serves a protective role [123]. Microglia produce apoE, which has been shown to moderate the inflammatory response while enhancing the phagocytosis of $A \beta$ aggregates by microglia [124-128]. However, in carriers of apoE4, increased levels of ferritin have been reported in the cerebral spinal fluid, suggesting that iron metabolism is altered in these individuals to promote increased iron retention [129]. This evidence reinforces the concept that increased brain iron adversely affects patients with AD. In fact, patients with HFE-associated hemochromatosis are subject to earlier onset of AD [130]. Since there is clinical evidence that iron chelation is beneficial to AD patients [131,132], the relationship between microglia, iron, and neurodegeneration appears to be well worth exploring.

\section{Concluding Remarks}

Understanding the role of iron in chronic inflammatory responses elicited by microglia is essential for finding new therapeutic strategies to treat neurodegenerative diseases. Although a substantial amount of effort has been put into deciphering the molecular network directly involved in brain iron 
metabolism, we still must pursue an in-depth understanding of how specific brain cells accumulate and use iron to carry out their various functions, both in normal and in disease conditions.

Author Contributions: I.C.N. and M.W.-R. wrote, reviewed, and edited this manuscript.

Funding: Supported by the National Institutes of Diabetes and Digestive and Kidney Disease under the award R01 DK064750. ICN is supported by the National Institute of Environmental Health Sciences under the award T32 ES016645.

Conflicts of Interest: The authors declare no conflict of interest.

\section{Abbreviations}

\begin{tabular}{|c|c|}
\hline Alzheimer's disease & $\mathrm{AD}$ \\
\hline familial Alzheimer's disease & FAD \\
\hline sporadic Alzheimer's disease & SAD \\
\hline neurodegeneration with brain iron accumulation & NBIA \\
\hline Parkinson's disease & PD \\
\hline Huntington's disease & HD \\
\hline amyotrophic lateral sclerosis & ALS \\
\hline multiple sclerosis & MS \\
\hline amyloid beta & $\mathrm{A} \beta$ \\
\hline transferrin & $\mathrm{Tf}$ \\
\hline Tf-bound iron & TBI \\
\hline transferrin receptor & TfR \\
\hline non-transferrin-bound iron & NTBI \\
\hline divalent metal transporter-1 & DMT1 \\
\hline labile iron pool & LIP \\
\hline central nervous system & CNS \\
\hline Blood-brain barrier & BBB \\
\hline brain microvascular endothelial cell & BMVEC \\
\hline transient receptor potential mucolipin-1 & TRPML1 \\
\hline ferritin & Ftn \\
\hline reactive oxygen species & ROS \\
\hline gamma-aminobutyric acid & GABA \\
\hline inducible nitric oxidase & iNOS \\
\hline N-methyl-D-aspartate & NMDA \\
\hline adenosine triphosphate & ATP \\
\hline 3-hydroxy-3-methyl-glutaryl-coenzyme A & HMG-Co \\
\hline tricarboxylic acid & TCA \\
\hline interferon gamma & IFN- $\gamma$ \\
\hline toll-like receptor & TLR \\
\hline tumor necrosis factor-alpha & $\mathrm{TNF}-\alpha$ \\
\hline interleukin-6 & IL-6 \\
\hline interleukin 1-beta & IL-1 $\beta$ \\
\hline interleukin-12 & IL-12 \\
\hline interleukin-10 & IL-10 \\
\hline C-C motif chemokine ligand-2 & CCL2 \\
\hline transforming growth factor-beta & TGF- $\beta$ \\
\hline insulin-like growth factor-1 & IGF-1 \\
\hline fibroblast growth factor & FGF \\
\hline nerve growth factor & NGF \\
\hline brain-derived growth factor & BDNF \\
\hline toll-like receptor 2 & TLR2 \\
\hline toll-like receptor 4 & TLR4 \\
\hline toll-like receptor 6 & TLR6 \\
\hline cluster of differentiation 33 & CD33 \\
\hline
\end{tabular}


cluster of differentiation 36

triggering receptor expressed on myeloid cells 2

apolipoprotein E

apolipoprotein $\mathrm{E} 4$

apolipoprotein E2
CD36

TREM2

apoE

apoE4

apoE2

\section{References}

1. Beard, J.L.; Connor, J.R. Iron status and neural functioning. Annu. Rev. Nutr. 2003, 23, 41-58. [CrossRef] [PubMed]

2. Hidalgo, C.; Carrasco, M.A.; Muñoz, P.; Núñez, M.T. A Role for Reactive Oxygen/Nitrogen Species and Iron on Neuronal Synaptic Plasticity. Antioxid. Redox Signal. 2007, 9, 245-255. [CrossRef] [PubMed]

3. Falkowska, A.; Gutowska, I.; Goschorska, M.; Nowacki, P.; Chlubek, D.; Baranowska-Bosiacka, I. Energy Metabolism of the Brain, Including the Cooperation between Astrocytes and Neurons, Especially in the Context of Glycogen Metabolism. Int. J. Mol. Sci. 2015, 16, 25959-25981. [CrossRef] [PubMed]

4. Magistretti, P.J.; Allaman, I. A cellular perspective on brain energy metabolism and functional imaging. Neuron 2015, 86, 883-901. [CrossRef] [PubMed]

5. Madsen, E.; Gitlin, J.D. Copper and Iron Disorders of the Brain. Annu. Rev. Neurosci. 2007, 30, $317-337$. [CrossRef] [PubMed]

6. Todorich, B.; Zhang, X.; Slagle-Webb, B.; Seaman, W.E.; Connor, J.R. Tim-2 is the receptor for H-ferritin on oligodendrocytes. J. Neurochem. 2008, 107, 1495-1505. [CrossRef] [PubMed]

7. Salvador, G.A. Iron in neuronal function and dysfunction. Biofactors 2010, 36, 103-110. [CrossRef] [PubMed]

8. Giampietro, R.; Spinelli, F.; Contino, M.; Colabufo, N.A. The Pivotal Role of Copper in Neurodegeneration: A New Strategy for the Therapy of Neurodegenerative Disorders. Mol. Pharm. 2018, 15, 808-820. [CrossRef] [PubMed]

9. Bowman, A.B.; Kwakye, G.F.; Herrero Hernandez, E.; Aschner, M. Role of manganese in neurodegenerative diseases. J. Trace Elem. Med. Biol. 2011, 25, 191-203. [CrossRef] [PubMed]

10. Szewczyk, B. Zinc homeostasis and neurodegenerative disorders. Front. Aging Neurosci. 2013, 5, 33. [CrossRef] [PubMed]

11. Muhoberac, B.B.; Vidal, R. Abnormal iron homeostasis and neurodegeneration. Front. Aging Neurosci. 2013, 5, 32. [CrossRef] [PubMed]

12. Ward, R.J.; Zucca, F.A.; Duyn, J.H.; Crichton, R.R.; Zecca, L. The role of iron in brain ageing and neurodegenerative disorders. Lancet Neurol. 2014, 13, 1045-1060. [CrossRef]

13. Thomsen, M.S.; Andersen, M.V.; Christoffersen, P.R.; Jensen, M.D.; Lichota, J.; Moos, T. Neurodegeneration with inflammation is accompanied by accumulation of iron and ferritin in microglia and neurons. Neurobiol. Dis. 2015, 81, 108-118. [CrossRef] [PubMed]

14. Li, K.; Reichmann, H. Role of Iron in Neurodegenerative Diseases. J. Neural Transm. 2016, 123, $389-399$. [CrossRef] [PubMed]

15. Mittelbronn, M.; Dietz, K.; Schluesener, H.J.; Meyermann, R. Local distribution of microglia in the normal adult human central nervous system differs by up to one order of magnitude. Acta Neuropathol. 2001, 101, 249-255. [PubMed]

16. Lloyd, A.F.; Davies, C.L.; Miron, V.E. Microglia: Origins, homeostasis, and roles in myelin repair. Curr. Opin. Neurobiol. 2017, 47, 113-120. [CrossRef] [PubMed]

17. Prinz, M.; Tay, T.L.; Wolf, Y.; Jung, S. Microglia: Unique and common features with other tissue macrophages. Acta Neuropathol. 2014, 128, 319-331. [CrossRef] [PubMed]

18. Ransohoff, R.M. A polarizing question: Do M1 and M2 microglia exist? Nat. Neurosci. 2016, 19, 987-991. [CrossRef] [PubMed]

19. Colonna, M.; Butovsky, O. Microglia Function in the Central Nervous System During Health and Neurodegeneration. Annu. Rev. Immunol. 2017, 35, 441-468. [CrossRef] [PubMed]

20. Squarzoni, P.; Thion, M.S.; Garel, S. Neuronal and microglial regulators of cortical wiring: Usual and novel guideposts. Front. Neurosci. 2015, 9, 248. [CrossRef] [PubMed]

21. Pollard, J.W. Trophic macrophages in development and disease. Nat. Rev. Immunol. 2009, 9, $259-270$. [CrossRef] [PubMed] 
22. Murray, P.J.; Wynn, T.A. Protective and pathogenic functions of macrophage subsets. Nat. Rev. Immunol. 2011, 11, 723-737. [CrossRef] [PubMed]

23. Tremblay, M.E.; Stevens, B.; Sierra, A.; Wake, H.; Bessis, A.; Nimmerjahn, A. The role of microglia in the healthy brain. J. Neurosci. 2011, 31, 16064-16069. [CrossRef] [PubMed]

24. Wake, H.; Moorhouse, A.J.; Miyamoto, A.; Nabekura, J. Microglia: Actively surveying and shaping neuronal circuit structure and function. Trends Neurosci. 2013, 36, 209-217. [CrossRef] [PubMed]

25. Erblich, B.; Zhu, L.; Etgen, A.M.; Dobrenis, K.; Pollard, J.W. Absence of colony stimulation factor-1 receptor results in loss of microglia, disrupted brain development and olfactory deficits. PLoS ONE 2011, 6, e26317. [CrossRef] [PubMed]

26. Schafer, D.P.; Lehrman, E.K.; Kautzman, A.G.; Koyama, R.; Mardinly, A.R.; Yamasaki, R.; Ransohoff, R.M.; Greenberg, M.E.; Barres, B.A.; Stevens, B. Microglia Sculpt Postnatal Neural Circuits in an Activity and Complement-Dependent Manner. Neuron 2012, 74, 691-705. [CrossRef] [PubMed]

27. Rathnasamy, G.; Ling, E.-A.; Kaur, C. Consequences of iron accumulation in microglia and its implications in neuropathological conditions. CNS Neurol. Dis. Drug Targets 2013, 12, 785-798. [CrossRef]

28. McCarthy, R.C.; Sosa, J.C.; Gardeck, A.M.; Baez, A.S.; Lee, C.H.; Wessling-Resnick, M. Inflammation-induced iron transport and metabolism by brain microglia. J. Biol. Chem. 2018, 293, 7853-7863. [CrossRef] [PubMed]

29. Hentze, M.W.; Muckenthaler, M.U.; Andrews, N.C. Review Balancing Acts: Molecular Control of Mammalian Iron Metabolism sequences of systemic iron overload result from chronic iron accumulation in tissues. Cell 2004, 117, 285-297. [CrossRef]

30. Moos, T.; Nielsen, T.R.; Skjørringe, T.; Morgan, E.H. Iron trafficking inside the brain. J. Neurochem. 2007, 103, 1730-1740. [CrossRef] [PubMed]

31. Anderson, G.J.; Frazer, D.M. Current understanding of iron homeostasis. Am. J. Clin. Nutr. 2017, 106, 1559S-1566S. [CrossRef] [PubMed]

32. Wessling-Resnick, M. Iron imports. III. Transfer of iron from the mucosa into circulation. Am. J. Physiol. Gastrointest. Liver Physiol. 2006, 290, G1-G6. [CrossRef] [PubMed]

33. McCarthy, R.C.; Kosman, D.J. Iron transport across the blood-brain barrier: Development, neurovascular regulation and cerebral amyloid angiopathy. Cell. Mol. Life Sci. 2015, 72, 709-727. [CrossRef] [PubMed]

34. Abbott, N.J.; Rönnbäck, L.; Hansson, E. Astrocyte-endothelial interactions at the blood-brain barrier. Nat. Rev. Neurosci. 2006, 7, 41-53. [CrossRef] [PubMed]

35. Rouault, T.A.; Cooperman, S. Brain Iron Metabolism. Semin. Pediatr. Neurol. 2006, 13, 142-148. [CrossRef] [PubMed]

36. Ke, Y.; Qian, Z.M. Brain iron metabolism: Neurobiology and neurochemistry. Prog. Neurobiol. 2007, 83, 149-173. [CrossRef] [PubMed]

37. Gunshin, H.; Mackenzie, B.; Berger, U.V.; Gunshin, Y.; Romero, M.F.; Boron, W.F.; Nussberger, S.; Gollan, J.L.; Hediger, M.A. Cloning and characterization of a mammalian proton-coupled metal-ion transporter. Nature 1997, 388, 482-488. [CrossRef] [PubMed]

38. Burdo, J.R.; Menzies, S.L.; Simpson, I.A.; Garrick, L.M.; Garrick, M.D.; Dolan, K.G.; Haile, D.J.; Beard, J.L.; Connor, J.R. Distribution of divalent metal transporter 1 and metal transport protein 1 in the normal and Belgrade rat. J. Neurosci. Res. 2001, 66, 1198-1207. [CrossRef] [PubMed]

39. Siddappa, A.J.M.; Rao, R.B.; Wobken, J.D.; Leibold, E.A.; Connor, J.R.; Georgieff, M.K. Developmental changes in the expression of iron regulatory proteins and iron transport proteins in the perinatal rat brain. J. Neurosci. Res. 2002, 68, 761-775. [CrossRef] [PubMed]

40. Enerson, B.E.; Drewes, L.R. The Rat Blood-Brain Barrier Transcriptome. J. Cereb. Blood Flow Metab. 2006, 26, 959-973. [CrossRef] [PubMed]

41. Moos, T.; Skjoerringe, T.; Gosk, S.; Morgan, E.H. Brain capillary endothelial cells mediate iron transport into the brain by segregating iron from transferrin without the involvement of divalent metal transporter 1. J. Neurochem. 2006, 98, 1946-1958. [CrossRef] [PubMed]

42. Skjorringe, T.; Burkhart, A.; Johnsen, K.B.; Moos, T. Divalent metal transporter 1 (DMT1) in the brain: Implications for a role in iron transport at the blood-brain barrier, and neuronal and glial pathology. Front. Mol. Neurosci. 2015, 8, 19. [PubMed]

43. Dong, X.-P.; Cheng, X.; Mills, E.; Delling, M.; Wang, F.; Kurz, T.; Xu, H. The type IV mucolipidosis-associated protein TRPML1 is an endolysosomal iron release channel. Nature 2008, 455, 992-996. [CrossRef] [PubMed] 
44. Grishchuk, Y.; Pena, K.A.; Coblentz, J.; King, V.E.; Humphrey, D.M.; Wang, S.L.; Kiselyov, K.I.; Slaugenhaupt, S.A. Impaired myelination and reduced brain ferric iron in the mouse model of mucolipidosis IV. Dis. Models Mech. 2015, 8, 1591-1601. [CrossRef] [PubMed]

45. Simpson, I.A.; Ponnuru, P.; Klinger, M.E.; Myers, R.L.; Devraj, K.; Coe, C.L.; Lubach, G.R.; Carruthers, A.; Connor, J.R. A novel model for brain iron uptake: Introducing the concept of regulation. J. Cereb. Blood Flow Metab. 2015, 35, 48-57. [CrossRef] [PubMed]

46. McCarthy, R.C.; Kosman, D.J. Ferroportin and exocytoplasmic ferroxidase activity are required for brain microvascular endothelial cell iron efflux. J. Biol. Chem. 2013, 288, 17932-17940. [CrossRef] [PubMed]

47. McCarthy, R.C.; Kosman, D.J. Glial cell ceruloplasmin and hepcidin differentially regulate iron efflux from brain microvascular endothelial cells. PLoS ONE 2014, 9, e89003. [CrossRef] [PubMed]

48. Duck, K.A.; Connor, J.R. Iron uptake and transport across physiological barriers. Biometals 2016, 29 , 573-591. [CrossRef] [PubMed]

49. Gutteridge, J.M. Ferrous ions detected in cerebrospinal fluid by using bleomycin and DNA damage. Clin. Sci. 1992, 82, 315-320. [CrossRef] [PubMed]

50. Ferreira, C.; Bucchini, D.; Martin, M.E.; Levi, S.; Arosio, P.; Grandchamp, B.; Beaumont, C. Early embryonic lethality of $\mathrm{H}$ ferritin gene deletion in mice. J. Biol. Chem. 2000, 275, 3021-3024. [CrossRef] [PubMed]

51. Thompson, K.; Menzies, S.; Muckenthaler, M.; Torti, F.M.; Wood, T.; Torti, S.V.; Hentze, M.W.; Beard, J.; Connor, J. Mouse brains deficient in $\mathrm{H}$-ferritin have normal iron concentration but a protein profile of iron deficiency and increased evidence of oxidative stress. J. Neurosci. Res. 2003, 71, 46-63. [CrossRef] [PubMed]

52. Li, W.; Garringer, H.J.; Goodwin, C.B.; Richine, B.; Acton, A.; VanDuyn, N.; Muhoberac, B.B.; Irimia-Dominguez, J.; Chan, R.J.; Peacock, M.; et al. Systemic and Cerebral Iron Homeostasis in Ferritin Knock-Out Mice. PLoS ONE 2015, 10, e0117435. [CrossRef] [PubMed]

53. Chiou, B.; Neal, E.H.; Bowman, A.B.; Lippmann, E.S.; Simpson, I.A.; Connor, J.R. Endothelial cells are critical regulators of iron transport in a model of the human blood-brain barrier. J. Cereb. Blood Flow Metab. 2018. [CrossRef] [PubMed]

54. Todorich, B.; Zhang, X.; Connor, J.R. H-ferritin is the major source of iron for oligodendrocytes. Glia 2011, 59, 927-935. [CrossRef] [PubMed]

55. Li, L.; Fang, C.J.; Ryan, J.C.; Niemi, E.C.; Lebron, J.A.; Bjorkman, P.J.; Arase, H.; Torti, F.M.; Torti, S.V.; Nakamura, M.C.; et al. Binding and uptake of H-ferritin are mediated by human transferrin receptor-1. Proc. Natl. Acad. Sci. USA 2010, 107, 3505-3510. [CrossRef] [PubMed]

56. Sakamoto, S.; Kawabata, H.; Masuda, T.; Uchiyama, T.; Mizumoto, C.; Ohmori, K.; Koeffler, H.P.; Kadowaki, N.; Takaori-Kondo, A. H-Ferritin Is Preferentially Incorporated by Human Erythroid Cells through Transferrin Receptor 1 in a Threshold-Dependent Manner. PLoS ONE 2015, 10, e0139915. [CrossRef] [PubMed]

57. Lill, R.; Hoffmann, B.; Molik, S.; Pierik, A.J.; Rietzschel, N.; Stehling, O.; Uzarska, M.A.; Webert, H.; Wilbrecht, C.; Mühlenhoff, U. The role of mitochondria in cellular iron-sulfur protein biogenesis and iron metabolism. Biochim. Biophys. Acta (BBA) Mol. Cell Res. 2012, 1823, 1491-1508. [CrossRef] [PubMed]

58. Alle, H.; Roth, A.; Geiger, J.R.P. Energy-efficient action potentials in hippocampal mossy fibers. Science 2009, 325, 1405-1408. [CrossRef] [PubMed]

59. Todorich, B.; Pasquini, J.M.; Garcia, C.I.; Paez, P.M.; Connor, J.R. Oligodendrocytes and myelination: The role of iron. Glia 2009, 57, 467-478. [CrossRef] [PubMed]

60. Yu, G.S.; Steinkirchner, T.M.; Rao, G.A.; Larkin, E.C. Effect of prenatal iron deficiency on myelination in rat pups. Am. J. Pathol. 1986, 125, 620-624. [PubMed]

61. Ortiz, E.; Pasquini, J.M.; Thompson, K.; Felt, B.; Butkus, G.; Beard, J.; Connor, J.R. Effect of manipulation of iron storage, transport, or availability on myelin composition and brain iron content in three different animal models. J. Neurosci. Res. 2004, 77, 681-689. [CrossRef] [PubMed]

62. Ashkenazi, R.; Ben-Shachar, D.; Youdim, M.B.H. Nutritional iron and dopamine binding sites in the rat brain. Pharmacol. Biochem. Behav. 1982, 17, 43-47. [CrossRef]

63. Adhami, V.M.; Husain, R.; Husain, R.; Seth, P.K. Influence of Iron Deficiency and Lead Treatment on Behavior and Cerebellar and Hippocampal Polyamine Levels in Neonatal Rats. Neurochem. Res. 1996, 21, 915-922. [CrossRef] [PubMed] 
64. Kwik-Uribe, C.L.; Gietzen, D.; German, J.B.; Golub, M.S.; Keen, C.L. Chronic Marginal Iron Intakes during Early Development in Mice Result in Persistent Changes in Dopamine Metabolism and Myelin Composition. J. Nutr. 2000, 130, 2821-2830. [CrossRef] [PubMed]

65. Kim, J.; Wessling-Resnick, M. Iron and mechanisms of emotional behavior. J. Nutr. Biochem. 2014, 25, 1101-1107. [CrossRef] [PubMed]

66. Kuhn, D.M.; Ruskin, B.; Lovenberg, W. Tryptophan Hydroxylase The role of oxygen, iron, and sulfhydryl groups as determinants of stability and catalytic activity. J. Biol. Chem. 1980, 255, 4137-4143. [PubMed]

67. Glinka, Y.; Gassen, M.; Youdim, M.B.H. Iron and Neurotransmitter Function in the Brain. In Metals and Oxidative Damage in Neurological Disorders; Connor, J.R., Ed.; Springer: Boston, MA, USA, 1997; pp. 1-22.

68. Bianco, L.E.; Wiesinger, J.; Earley, C.J.; Jones, B.C.; Beard, J.L. Iron deficiency alters dopamine uptake and response to L-DOPA injection in Sprague-Dawley rats. J. Neurochem. 2008, 106, 205-215. [CrossRef] [PubMed]

69. Yehuda, S.; Youdim, M.B. Brain iron: A lesson from animal models. Am. J. Clin. Nutr. 1989, 50, 618-629. [CrossRef] [PubMed]

70. Yehuda, S. Neurochemical basis of behavioral effects of brain iron deficiency in animals. In Brain, Behavior and Iron in the Infant Diet; Dobbing, J., Ed.; Springer: London, UK, 1990; pp. 63-76.

71. Erikson, K.M.; Jones, B.C.; Hess, E.J.; Zhang, Q.; Beard, J.L. Iron deficiency decreases dopamine D 1 and D 2 receptors in rat brain. Pharmacol. Biochem. Behav. 2001, 69, 409-418. [CrossRef]

72. Chen, Q.; Connor, J.R.; Beard, J.L. Brain Iron, Transferrin and Ferritin Concentrations Are Altered in Developing Iron-Deficient Rats. J. Nutr. 1995, 125, 1529-1535. [PubMed]

73. Waldmeier, P.C.; Buchle, A.M.; Steulet, A.F. Inhibition of catechol-O-methyltransferase (COMT) as well as tyrosine and tryptophan hydroxylase by the orally active iron chelator, 1,2-dimethyl-3-hydroxypyridin-4-one (L1, CP20), in rat brain in vivo. Biochem. Pharmacol. 1993, 45, 2417-2424. [CrossRef]

74. Taneja, V.; Mishra, K.; Agarwal, K.N. Effect of early iron deficiency in rat on the gamma-aminobutyric acid shunt in brain. J. Neurochem. 1986, 46, 1670-1674. [CrossRef] [PubMed]

75. Li, D. Effects of iron deficiency on iron distribution and gamma-aminobutyric acid (GABA) metabolism in young rat brain tissues. Hokkaido J. Med. Sci. 1998, 73, 215-225. [PubMed]

76. Appel, S.H.; Zhao, W.; Beers, D.R.; Henkel, J.S. The Microglial-Motoneuron dialogue in ALS. Acta Myol. 2011, 30, 4. [PubMed]

77. Sica, A.; Mantovani, A. Macrophage plasticity and polarization: In vivo veritas. J. Clin. Investig. 2012, 122, 787-795. [CrossRef] [PubMed]

78. Farber, N.B.; Kim, S.H.; Dikranian, K.; Jiang, X.P.; Heinkel, C. Receptor mechanisms and circuitry underlying NMDA antagonist neurotoxicity. Mol. Psychiatry 2002, 7, 32-43. [CrossRef] [PubMed]

79. Bai, N.; Aida, T.; Yanagisawa, M.; Katou, S.; Sakimura, K.; Mishina, M.; Tanaka, K. NMDA receptor subunits have different roles in NMDA-induced neurotoxicity in the retina. Mol. Brain 2013, 6, 34. [CrossRef] [PubMed]

80. Franca-Costa, J.; Van Weyenbergh, J.; Boaventura, V.S.; Luz, N.F.; Malta-Santos, H.; Oliveira, M.C.; Santos de Campos, D.C.; Saldanha, A.C.; dos-Santos, W.L.; Bozza, P.T.; et al. Arginase I, polyamine, and prostaglandin E2 pathways suppress the inflammatory response and contribute to diffuse cutaneous leishmaniasis. J. Infect. Dis. 2015, 211, 426-435. [CrossRef] [PubMed]

81. Wes, P.D.; Holtman, I.R.; Boddeke, E.W.; Moller, T.; Eggen, B.J. Next generation transcriptomics and genomics elucidate biological complexity of microglia in health and disease. Glia 2016, 64, 197-213. [CrossRef] [PubMed]

82. Butovsky, O.; Jedrychowski, M.P.; Moore, C.S.; Cialic, R.; Lanser, A.J.; Gabriely, G.; Koeglsperger, T.; Dake, B.; $\mathrm{Wu}$, P.M.; Doykan, C.E.; et al. Identification of a unique TGF- $\beta$-dependent molecular and functional signature in microglia. Nat. Neurosci. 2014, 17, 131-143. [CrossRef] [PubMed]

83. Hickman, S.E.; Kingery, N.D.; Ohsumi, T.; Borowsky, M.; Wang, L.-C.; Means, T.K.; Khoury, J.E. The Microglial Sensome Revealed by Direct RNA Sequencing. Nat. Neurosci. 2013, 16, 1896-1905. [CrossRef] [PubMed]

84. Chiu, I.M.; Morimoto, E.T.A.; Goodarzi, H.; Liao, J.T.; O’Keeffe, S.; Phatnani, H.P.; Muratet, M.; Carroll, M.C.; Levy, S.; Tavazoie, S.; et al. A neurodegeneration-specific gene-expression signature of acutely isolated microglia from an amyotrophic lateral sclerosis mouse model. Cell Rep. 2013, 4, 385-401. [CrossRef] [PubMed] 
85. Wessling-Resnick, M. Iron homeostasis and the inflammatory response. Annu. Rev. Nutr. 2010, 30, 105-122. [CrossRef] [PubMed]

86. Xu, H.; Wang, Y.; Song, N.; Wang, J.; Jiang, H.; Xie, J. New Progress on the Role of Glia in Iron Metabolism and Iron-Induced Degeneration of Dopamine Neurons in Parkinson's Disease. Front. Mol. Neurosci. 2018, 10, 455. [CrossRef] [PubMed]

87. Wang, J.; Song, N.; Jiang, H.; Wang, J.; Xie, J. Pro-inflammatory cytokines modulate iron regulatory protein 1 expression and iron transportation through reactive oxygen/nitrogen species production in ventral mesencephalic neurons. Biochim. Biophys. Acta 2013, 1832, 618-625. [CrossRef] [PubMed]

88. Kaur, C.; Ling, E.A. Increased expression of transferrin receptors and iron in amoeboid microglial cells in postnatal rats following an exposure to hypoxia. Neurosci. Lett. 1999, 262, 183-186. [CrossRef]

89. Urrutia, P.; Aguirre, P.; Esparza, A.; Tapia, V.; Mena, N.P.; Arredondo, M.; Gonzalez-Billault, C.; Nunez, M.T. Inflammation alters the expression of DMT1, FPN1 and hepcidin, and it causes iron accumulation in central nervous system cells. J. Neurochem. 2013, 126, 541-549. [CrossRef] [PubMed]

90. Holland, R.; McIntosh, A.L.; Finucane, O.M.; Mela, V.; Rubio-Araiz, A.; Timmons, G.; McCarthy, S.A.; Gun'ko, Y.K.; Lynch, M.A. Inflammatory microglia are glycolytic and iron retentive and typify the microglia in APP/PS1 mice. Brain Behav. Immun. 2018, 68, 183-196. [CrossRef] [PubMed]

91. Gaasch, J.A.; Lockman, P.R.; Geldenhuys, W.J.; Allen, D.D.; Van der Schyf, C.J. Brain Iron Toxicity: Differential Responses of Astrocytes, Neurons, and Endothelial Cells. Neurochem. Res. 2007, 32, 1196-1208. [CrossRef] [PubMed]

92. Wessling-Resnick, M. Crossing the Iron Gate: Why and How Transferrin Receptors Mediate Viral Entry. Annu. Rev. Nutr. 2018, 38, 431-458. [CrossRef] [PubMed]

93. Tanzi, R.E. The Genetics of Alzheimer Disease. Cold Spring Harb. Perspect. Med. 2012, 2, a006296. [CrossRef] [PubMed]

94. Belaidi, A.A.; Bush, A.I. Iron neurochemistry in Alzheimer's disease and Parkinson's disease: Targets for therapeutics. J. Neurochem. 2016, 139, 179-197. [CrossRef] [PubMed]

95. Praticò, D. Oxidative stress hypothesis in Alzheimer's disease: A reappraisal. Trends Pharmacol. Sci. 2008, 29, 609-615. [CrossRef] [PubMed]

96. Lane, D.J.R.; Ayton, S.; Bush, A.I. Iron and Alzheimer's Disease: An Update on Emerging Mechanisms. J. Alzheimers Dis. 2018, 64, S379-S395. [CrossRef] [PubMed]

97. Reddy, K.; Cusack, C.L.; Nnah, I.C.; Khayati, K.; Saqcena, C.; Huynh, T.B.; Noggle, S.A.; Ballabio, A.; Dobrowolski, R. Dysregulation of Nutrient Sensing and CLEARance in Presenilin Deficiency. Cell Rep. 2016, 14, 2166-2179. [CrossRef] [PubMed]

98. Smith, C.D.; Carney, J.M.; Starke-Reed, P.E.; Oliver, C.N.; Stadtman, E.R.; Floyd, R.A.; Markesbery, W.R. Excess brain protein oxidation and enzyme dysfunction in normal aging and in Alzheimer disease. Proc. Natl. Acad. Sci. USA 1991, 88, 10540-10543. [CrossRef] [PubMed]

99. Mecocci, P.; MacGarvey, U.; Beal, M.F. Oxidative damage to mitochondrial DNA is increased in Alzheimer's disease. Ann. Neurol. 1994, 36, 747-751. [CrossRef] [PubMed]

100. Good, P.F.; Werner, P.; Hsu, A.; Olanow, C.W.; Perl, D.P. Evidence for Neuronal Oxidative Damage in Alzheimer's Disease. Am. J. Pathol. 1996, 149, 21-28. [PubMed]

101. Lovell, M.A.; Ehmann, W.D.; Butler, S.M.; Markesbery, W.R. Elevated thiobarbituric acid-reactive substances and antioxidant enzyme activity in the brain in Alzheimer's disease. Neurology 1995, 45, 1594-1601. [CrossRef] [PubMed]

102. Zhu, X.; Su, B.; Wang, X.; Smith, M.A.; Perry, G. Causes of oxidative stress in Alzheimer disease. Cell. Mol. Life Sci. 2007, 64, 2202-2210. [CrossRef] [PubMed]

103. Bonda, D.J.; Wang, X.; Perry, G.; Nunomura, A.; Tabaton, M.; Zhu, X.; Smith, M.A. Oxidative stress in Alzheimer disease: A possibility for prevention. Neuropharmacology 2010, 59, 290-294. [CrossRef] [PubMed]

104. Bush, A.I. The metal theory of Alzheimer's disease. J. Alzheimers Dis. 2013, 33 (Suppl. 1), S277-S281. [CrossRef] [PubMed]

105. Zeineh, M.M.; Chen, Y.; Kitzler, H.H.; Hammond, R.; Vogel, H.; Rutt, B.K. Activated iron-containing microglia in the human hippocampus identified by magnetic resonance imaging in Alzheimer disease. Neurobiol. Aging 2015, 36, 2483-2500. [CrossRef] [PubMed]

106. Filomeni, G.; Bolaños, J.P.; Mastroberardino, P.G. Redox Status and Bioenergetics Liaison in Cancer and Neurodegeneration. Int. J. Cell Biol. 2012, 2012, 659645. [CrossRef] [PubMed] 
107. Di Paolo, G.; Kim, T.-W. Linking lipids to Alzheimer's disease: Cholesterol and beyond. Nat. Rev. Neurosci. 2011, 12, 284-296. [CrossRef] [PubMed]

108. Peters, D.G.; Pollack, A.N.; Cheng, K.C.; Sun, D.; Saido, T.; Haaf, M.P.; Yang, Q.X.; Connor, J.R.; Meadowcroft, M.D. Dietary lipophilic iron alters amyloidogenesis and microglial morphology in Alzheimer's disease knock-in APP mice. Metallomics 2018, 10, 426-443. [CrossRef] [PubMed]

109. Yu, J.; Guo, Y.; Sun, M.; Li, B.; Zhang, Y.; Li, C. Iron is a potential key mediator of glutamate excitotoxicity in spinal cord motor neurons. Brain Res. 2009, 1257, 102-107. [CrossRef] [PubMed]

110. Yang, W.S.; Stockwell, B.R. Ferroptosis: Death by Lipid Peroxidation. Trends Cell. Biol. 2016, 26, $165-176$. [CrossRef] [PubMed]

111. Heneka, M.T.; Carson, M.J.; Khoury, J.E.; Landreth, G.E.; Brosseron, F.; Feinstein, D.L.; Jacobs, A.H.; Wyss-Coray, T.; Vitorica, J.; Ransohoff, R.M.; et al. Neuroinflammation in Alzheimer's disease. Lancet Neurol. 2015, 14, 388-405. [CrossRef]

112. El Khoury, J.B.; Moore, K.J.; Means, T.K.; Leung, J.; Terada, K.; Toft, M.; Freeman, M.W.; Luster, A.D. CD36 mediates the innate host response to beta-amyloid. J. Exp. Med. 2003, 197, 1657-1666. [CrossRef] [PubMed]

113. Heneka, M.T.; Kummer, M.P.; Stutz, A.; Delekate, A.; Schwartz, S.; Vieira-Saecker, A.; Griep, A.; Axt, D.; Remus, A.; Tzeng, T.-C.; et al. NLRP3 is activated in Alzheimer's disease and contributes to pathology in APP/PS1 mice. Nature 2013, 493, 674-678. [CrossRef] [PubMed]

114. Guerreiro, R.; Wojtas, A.; Bras, J.; Carrasquillo, M.; Rogaeva, E.; Majounie, E.; Cruchaga, C.; Sassi, C.; Kauwe, J.S.K.; Younkin, S.; et al. Alzheimer Genetic Analysis Group, T.A.G.A. TREM2 variants in Alzheimer's disease. N. Engl. J. Med. 2013, 368, 117-127. [CrossRef] [PubMed]

115. Atagi, Y.; Liu, C.-C.; Painter, M.M.; Chen, X.-F.; Verbeeck, C.; Zheng, H.; Li, X.; Rademakers, R.; Kang, S.S.; $\mathrm{Xu}, \mathrm{H}$; ; et al. Apolipoprotein E Is a Ligand for Triggering Receptor Expressed on Myeloid Cells 2 (TREM2). J. Biol. Chem. 2015, 290, 26043-26050. [CrossRef] [PubMed]

116. Bailey, C.C.; DeVaux, L.B.; Farzan, M. The Triggering Receptor Expressed on Myeloid Cells 2 Binds Apolipoprotein E. J. Biol. Chem. 2015, 290, 26033-26042. [CrossRef] [PubMed]

117. Wang, Y.; Cella, M.; Mallinson, K.; Ulrich, J.D.; Young, K.L.; Robinette, M.L.; Gilfillan, S.; Krishnan, G.M.; Sudhakar, S.; Zinselmeyer, B.H.; et al. TREM2 Lipid Sensing Sustains the Microglial Response in an Alzheimer's Disease Model. Cell 2015, 160, 1061-1071. [CrossRef] [PubMed]

118. Yeh, F.L.; Wang, Y.; Tom, I.; Gonzalez, L.C.; Sheng, M. TREM2 Binds to Apolipoproteins, Including APOE and CLU/APOJ, and Thereby Facilitates Uptake of Amyloid-Beta by Microglia. Neuron 2016, 91, 328-340. [CrossRef] [PubMed]

119. Yuan, P.; Condello, C.; Keene, C.D.; Wang, Y.; Bird, T.D.; Paul, S.M.; Luo, W.; Colonna, M.; Baddeley, D.; Grutzendler, J. TREM2 Haplodeficiency in Mice and Humans Impairs the Microglia Barrier Function Leading to Decreased Amyloid Compaction and Severe Axonal Dystrophy. Neuron 2016, 90, 724-739. [CrossRef] [PubMed]

120. Jay, T.R.; Hirsch, A.M.; Broihier, M.L.; Miller, C.M.; Neilson, L.E.; Ransohoff, R.M.; Lamb, B.T.; Landreth, G.E. Disease Progression-Dependent Effects of TREM2 Deficiency in a Mouse Model of Alzheimer's Disease. J. Neurosci. 2017, 37, 637-647. [CrossRef] [PubMed]

121. Ulland, T.K.; Song, W.M.; Huang, S.C.-C.; Ulrich, J.D.; Sergushichev, A.; Beatty, W.L.; Loboda, A.A.; Zhou, Y.; Cairns, N.J.; Kambal, A.; et al. TREM2 Maintains Microglial Metabolic Fitness in Alzheimer's Disease. Cell 2017, 170, 649-663. [CrossRef] [PubMed]

122. Zhao, Y.; Wu, X.; Li, X.; Jiang, L.L.; Gui, X.; Liu, Y.; Sun, Y.; Zhu, B.; Pina-Crespo, J.C.; Zhang, M.; et al. TREM2 Is a Receptor for beta-Amyloid that Mediates Microglial Function. Neuron 2018, 97, 1023-1031. [CrossRef] [PubMed]

123. Hyman, B.T.; Holtzman, D.M. Apolipoprotein E levels and Alzheimer risk. Ann. Neurol. 2015, 77, $204-205$. [CrossRef] [PubMed]

124. Terwel, D.; Steffensen, K.R.; Verghese, P.B.; Kummer, M.P.; Gustafsson, J.-A.; Holtzman, D.M.; Heneka, M.T. Critical Role of Astroglial Apolipoprotein E and Liver X Receptor- $\alpha$ Expression for Microglial A $\beta$ Phagocytosis. J. Neurosci. 2011, 31, 7049-7059. [CrossRef] [PubMed]

125. Cammer, W. Oligodendrocyte-Associated Enzymes. In Oligodendroglia. Advances in Neurochemistry; William, N., Ed.; Springer: Boston, MA, USA, 1984; pp. 199-232. 
126. Xu, Q.; Li, Y.; Cyras, C.; Sanan, D.A.; Cordell, B. Isolation and characterization of apolipoproteins from murine microglia. Identification of a low density lipoprotein-like apolipoprotein J-rich but E-poor spherical particle. J. Biol. Chem. 2000, 275, 31770-31777. [CrossRef] [PubMed]

127. Cudaback, E.; Li, X.; Montine, K.S.; Montine, T.J.; Keene, C.D. Apolipoprotein E isoform-dependent microglia migration. FASEB J. 2011, 25, 2082-2091. [CrossRef] [PubMed]

128. Mandrekar-Colucci, S.; Karlo, J.C.; Landreth, G.E. Mechanisms underlying the rapid peroxisome proliferator-activated receptor- $\gamma$-mediated amyloid clearance and reversal of cognitive deficits in a murine model of Alzheimer's disease. J. Neurosci. 2012, 32, 10117-10128. [CrossRef] [PubMed]

129. Ayton, S.; Faux, N.G.; Bush, A.I. Alzheimer's Disease Neuroimaging Initiative, A.s.D.N. Ferritin levels in the cerebrospinal fluid predict Alzheimer's disease outcomes and are regulated by APOE. Nat. Commun. 2015, 6, 6760. [CrossRef] [PubMed]

130. Ali-Rahmani, F.; Schengrund, C.-L.; Connor, J.R. HFE gene variants, iron, and lipids: A novel connection in Alzheimer's disease. Front. Pharmacol. 2014, 5, 165. [CrossRef] [PubMed]

131. McLachlan, D.R.C.; Kruck, T.P.A.; Kalow, W.; Andrews, D.F.; Dalton, A.J.; Bell, M.Y.; Smith, W.L. Intramuscular desferrioxamine in patients with Alzheimer's disease. Lancet 1991, 337, 1304-1308. [CrossRef]

132. Palanimuthu, D.; Poon, R.; Sahni, S.; Anjum, R.; Hibbs, D.; Lin, H.Y.; Bernhardt, P.V.; Kalinowski, D.S.; Richardson, D.R. A novel class of thiosemicarbazones show multi-functional activity for the treatment of Alzheimer's disease. Eur. J. Med. Chem. 2017, 139, 612-632. [CrossRef] [PubMed]

(C) 2018 by the authors. Licensee MDPI, Basel, Switzerland. This article is an open access article distributed under the terms and conditions of the Creative Commons Attribution (CC BY) license (http://creativecommons.org/licenses/by/4.0/). 